\title{
Overexpression of colorectal cancer oncogene CHRDL2 predicts a poor prognosis
}

\author{
Jian Sun ${ }^{1, *}$, Xuan Liu ${ }^{2, *}$, Hong Gao ${ }^{1}$, Long Zhang ${ }^{1}$, Qing $\mathrm{Ji}^{2}$, Ziyuan Wang ${ }^{1}$, Lihong \\ Zhou' ${ }^{2}$, Yan Wang ${ }^{3}$, Hua Sui ${ }^{2}$, Zhongze Fan', ${ }^{1}$ Qi Li ${ }^{2}$ \\ ${ }^{1}$ Interventional Cancer Institute of Integrative Medicine \& Putuo Hospital, Shanghai University of Traditional Chinese \\ Medicine, Shanghai 200062, China \\ ${ }^{2}$ Department of Medical Oncology, Shuguang Hospital, Shanghai University of Traditional Chinese Medicine, Shanghai \\ 201203, China \\ ${ }^{3}$ Cancer Institute of Traditional Chinese Medicine \& Longhua Hospital, Shanghai University of Traditional Chinese Medicine, \\ Shanghai 200032, China \\ *These authors have contributed equally to this work
}

Correspondence to: Qi Li, email: Lzwf@hotmail.com

Keywords: colorectal cancer, BMP, CHRDL2, proliferation, apoptosis

Received: July 06, $2016 \quad$ Accepted: November 07, 2016

Published: December 20, 2016

\section{ABSTRACT}

Bone morphogenetic proteins (BMPs) both promote and suppress tumorigenesis, and multiple BMP antagonists reportedly contribute to cancer progression. In this study, we demonstrated that the BMP antagonist Chordin-like 2 (CHRDL2) is upregulated in colorectal cancer (CRC) tissues, and that CHRDL2 levels correlate with clinical features of CRC patients, including tumor size, TNM staging, and tumor differentiation. In addition, survival rate and Cox proportional hazards model analyses showed that high CHRDL2 levels correlate with a poor prognosis in CRC. Moreover, CHRDL2 promoted CRC cell proliferation in vitro and in vivo, perhaps through upregulation of Cyclin D1 and down-regulation of P21. Co-immunoprecipitation assays showed that CHRDL2 bound to BMPs, which inhibited p-Smad1/5, thereby promoting CRC cell proliferation and inhibiting apoptosis. These results suggest CHRDL2 could serve as a biomarker of poor prognosis in CRC, and provide evidence that CHRDL2 acts as an oncogene in human CRC, making it a novel potential therapeutic target.

\section{INTRODUCTION}

Colorectal cancer (CRC) is the third most common malignant tumor. Approximately 608, 000 people die of colorectal cancer each year, accounting for $8 \%$ of the total number of deaths worldwide [1]. The 5-years overall survival (OS) rates after initial colorectal surgery in CRC patients is negatively correlated with the degree of differentiation, depth of invasion, TNM stages, and lymph node metastasis [2, 3]. Recent studies showed that changes in cytokine signaling networks, such as transforming growth factor (TGF- $\beta$ ), tumor necrosis factor (TNF), and interleukin (IL), contribute to tumor progression CRC [4].

The TGF- $\beta$ superfamily of proteins regulates tumor cell differentiation, proliferation, migration, and apoptosis [5-7]. The TGF- $\beta$ superfamily is a set of multifunctional proteins including TGF- $\beta$, Bone Morphogenetic Proteins (BMPs), Growth Differentiation Factors (GDFs), Glial- derived Neurotrophic Factors (GDNFs), Inhibits, Nodal, Activins, Lefty, and Mülllerian Inhibiting Substance (MIS). This superfamily also includestwo kinds of receptors, which are intracellular signaling mediators for the TGF- $\beta$ superfamily [5]. Type I receptors include Activin and Nodal, whose signalsaretransduced through Smad2 and Smad3. Type II receptors include BMPs and GDFs, which transduce signals through Smad1, Smad5, and Smad8 [8]. Extracellular antagonists tothe TGF- $\beta$ superfamily are secretory proteins that bind to TGF- $\beta$ superfamily ligands to interfere with their function. These antagonists, including Noggin, Follistatin, Sclerostin, Chordin, Cerberus, and Gremlin, downregulate signaling by the TGF- $\beta$ superfamily and promote tumor development. By antagonizing BMP2, Noggin accelerates the proliferation of gastric cancer cells [9]. Follistatin, an antagonist of Activin, promotescancer cell survival [10]. Gremlin-1, an antagonist of BMPs, induces cell migration, invasion, and proliferation [11]. 
Bone morphogenic proteins (BMPs) belong to the TGF- $\beta$ superfamily and help to control colonic epithelial cell renewal, proliferation, and differentiation, and also possess potent antitumor activity [12]. Signaling by BMPs is triggered by BMP ligands binding to BMP receptors (BMPRs) followed by Smad1/5/8 activation. Activation of BMP signaling can promote apoptosis of mature colonic epithelial cells, thereby maintaining the dynamic balance of colonic epithelial cell proliferation and differentiation $[13,14]$. Extracellular antagonists such as Noggin can inhibit BMP signaling in colon stem cells, which is necessary for the self renewal and proliferation of intestinal crypt stem cells $[13,15]$. Recent research has shown that BMP signaling is lost or blocked in CRC, stemming from mutations in the BMPR and Smad genes and resulting in low expression of BMPs as well as highexpression of BMP antagonists [16-19].

Chordin-like 2 (CHRDL2) is an antagonist of BMPs that prevents them from interacting with their cognate cell surface receptors [20]. Although a previous study showed higher levels of CHRDL2 mRNA in breast cancer [21], CHRDL2's role in tumorigenesis remains largely unknown. Here, we measured CHRDL2 levels in human CRC tissue to investigate potential correlations between CHRDL2 expression and CRC clinicopathologic features as well as patient prognosis. We also investigated CHRDL2's role in CRC cell cycle progression. We showed that CHRDL2 was overexpressed in CRC, and this correlated with a low survival rate and poor prognosis. Furthermore, we showed that overexpression of CHRDL2 in CRC cell lines accelerated cell growth in vitro and promoted tumorigenesis in vivo, whereas knockdown of CHRDL2 showed the opposite effect. We also showed that CHRDL2 could block the activation of Smad1/5, as well as proliferation-inhibition and apoptosis induction by BMP2 in CRC cells. Our data suggest that CHRDL2 acts as an oncogene in CRC and might be a potential therapeutic target for CRC.

\section{RESULTS}

\section{CHRDL2 variant I is the major gene type in CRC}

Ten CHRDL2 variants were previously identified in various tissues [22]. To study the gene structure of CHRDL2 in CRC, the CHRDL2 gene open reading frame sequences of five pairs of colorectal cancer tissue and their matched normal tissues ( $\mathrm{N}$, normal tissue, $\mathrm{T}$, tumor tissue) were amplified by RT-PCR. The PCR products were separated and visualized by electrophoresis (Supplementary Figure 1A): Four lanes (T1, T3, T4, N1) were found to have 4 product bands (B1, B2, B3, B4), two samples (T2, N3) having a major band (B1), two samples (T5, N5) a weak band (B2), and two lanes (N2, N4) no bands (B2). PCR products were subsequently isolated, purified, subcloned and sequenced.
The CHRDL2 RT-PCR product (B1) was identified to be the CHRDL2 variant I (GenBank Acc. No. AY279090.1), and B2 and B4 were non-specific sequences while B3 was identified as a new CHRDL2 (BNF1) variant (AEV56635.1). As shown in Supplementary Figure 1B, the amino acid sequence of $\mathrm{B} 1$ is the CHRDL2 variant I (AY279090.1) while 293 amino acids were deleted in B3 (AEV56635.1). CR2 and CR3 are located in such deleted area. These data revealed that CHRDL2 variant I was the major CHRDL2 gene type in CRC tissues while the new CHRDL2 (BNF1) variant (AEV56635.1) was expressed at low levels in colorectal cancer and normal tissue. CR2 and CR3 deletion may cause the inactivation of CHRDL2 gene; therefore, we selected the CHRDL2 variant I gene for further functional studies.

\section{Higher CHRDL2 levels in CRCs are correlated with clinical features and pathologic parameters of CRCs patients}

To investigate the expression status of CHRDL2 gene in CRCs, we quantified mRNA levels of CHRDL2 by Quantitative RT-PCR (QRT-PCR) in 60 pairs of primary tumors and their matched adjacent normal tissues. The result showed that $C H R D L 2$ mRNA levels were markedly higher in CRC samples than in their adjacent normal tissue counterparts $(P<0.001$; Figure $1 \mathrm{~A})$. Immunohistochemistry analyses further confirmed the upregulation of CHRDL2 in CRC samples. Even in interface areas, CHRDL2 was still overexpressed in tumor areas compared with normal areas (Figure 1B). The expression of CHRDL2 protein was higher in colorectal adenocarcinoma and in the CRC samples than in their adjacent normal tissue counterparts $(P<0.001)$ (Figure 1C). Figure 1D showed that CHRDL2 levels are higher in poorly- and moderatelydifferentiated adenocarcinoma than in well-differentiated adenocarcinoma. To compute the correlation between CHRDL2 expression and clinical and pathological parameters, the samples were grouped into high CHRDL2 level (staining immunohistochemical score $>4$ ) and low CHRDL2 level (staining immunohistochemical score $\leq 4$ ) groups. The correlations between CHRDL2 expression and clinical and pathological characteristics are presented in Table 1. High CHRDL2 levels correlated with larger tumor size $(P<0.01)$, later TNM staging $(P<0.01)$, and poor tumor differentiation $(P<0.01)$. However, there was no correlation between CHRDL2 protein expression and tumor location, gender, depth of infiltration, lymph node metastasis, or age.

\section{Higher CHRDL2 levels correlate with poor prognosis in CRC}

We used the Kaplan-Meier analysis to analyze CRC patient survival and detect any potential correlations between survival and CHRDL2 levels. In this study, during the follow-up time of 60 months 46 patients with CRC 




B Adenocarcinoma

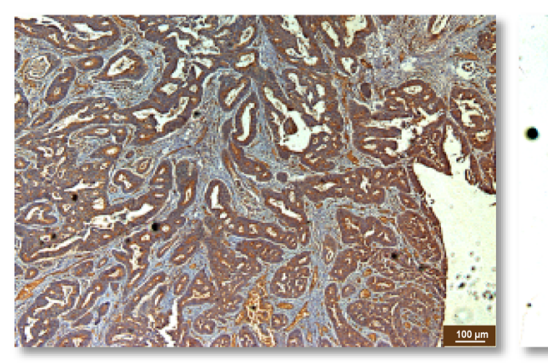

Interface area

Normal tissue

D

\section{Well differentiated adenocarcinoma}

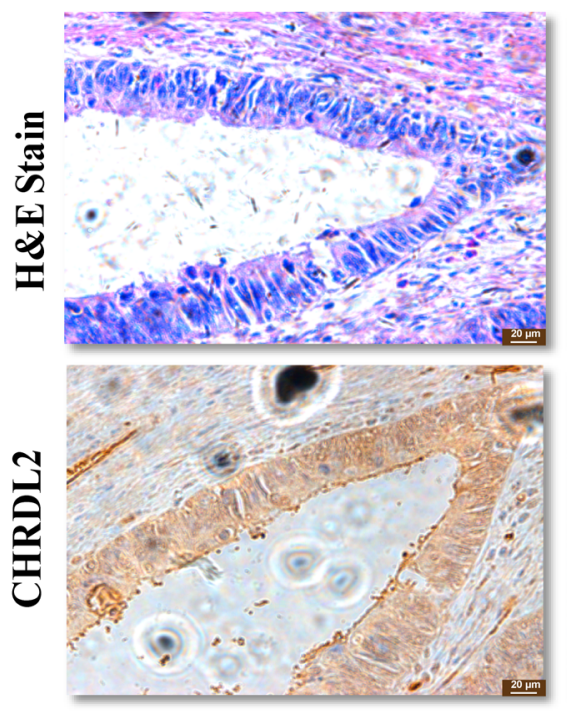

\section{Morderately differentiated adenocarcinoma}
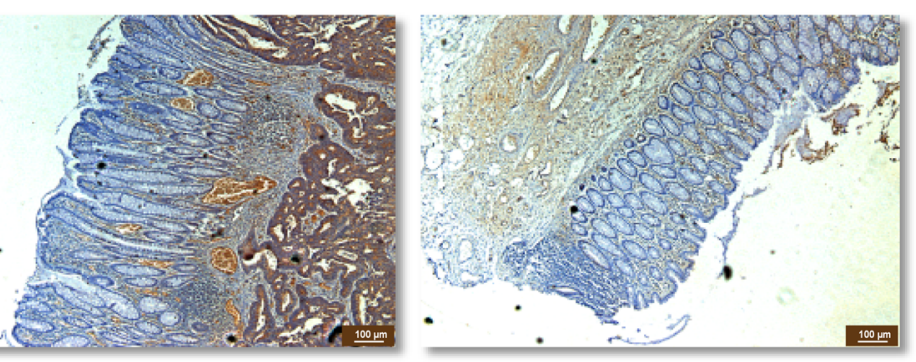

\section{Poorly differentiated adenocarcinoma}


Figure 1: CHRDL2 expression is significantly increased in CRC tissues. A. Quantitative RT-PCR of CHRDL2 mRNA expression levels in 60 paired human CRCs and normal tissues. CHRDL2 expression levels were normalized by those of GAPDH. Data were calculated from triplicate measurements. T, tumor samples. N, matched normal tissues. B. Representative images of immunohistochemical staining of CHRDL2 in 125 human CRC patients. C. Pathologic scores of CHRDL2 in CRC tissues. The scale bar represents $100 \mu \mathrm{m}$. Values were expressed as mean $\pm \mathrm{SD}$. $(* * * p<0.001)$. D. Immunohistochemistry images for CHRDL2 in three differentiated degree human CRC samples. Hematoxylin-eosin (H\&E) stain of the same samples is also shown. The scale bar represents $20 \mu \mathrm{m}$. 
Table 1: Correlation of CHRDL2 expression with clinicopathologic features in CRC tissues

\begin{tabular}{|c|c|c|c|c|}
\hline \multirow{2}{*}{$\begin{array}{l}\text { Clinicopathologic } \\
\text { features }\end{array}$} & \multicolumn{4}{|c|}{ Expression of CHRDL2 protein(IHC) } \\
\hline & Total cases & High expression & Low expression & $P$ values \\
\hline Age(years) & & & & 0.911 \\
\hline$<60$ & 76 & 38 & 38 & \\
\hline$\geq 60$ & 49 & 24 & 25 & \\
\hline Gender & & & & 0.792 \\
\hline Female & 59 & 30 & 29 & \\
\hline Male & 66 & 32 & 34 & \\
\hline Tumor diameter $(\mathrm{cm})$ & & & & $0.009 * *$ \\
\hline$\leq 5$ & 71 & 28 & 43 & \\
\hline$>5$ & 54 & 34 & 20 & \\
\hline Tumor location & & & & 0.858 \\
\hline Colon & 69 & 35 & 34 & \\
\hline Rectum & 56 & 27 & 29 & \\
\hline Depth of infiltration & & & & 0.385 \\
\hline $\begin{array}{l}\text { Submucosa,musculeris } \\
\text { propria }\end{array}$ & 28 & 15 & 13 & \\
\hline Subserosa & 66 & 29 & 37 & \\
\hline $\begin{array}{l}\text { To the surrounding } \\
\text { tissue }\end{array}$ & 31 & 18 & 13 & \\
\hline Histologic type & & & & $0.023 *$ \\
\hline Well differentiated & 56 & 22 & 34 & \\
\hline $\begin{array}{l}\text { Morderately } \\
\text { differentiated }\end{array}$ & 49 & 25 & 24 & \\
\hline Poorly differentiated & 20 & 15 & 5 & \\
\hline TNM staging & & & & $0.002 * *$ \\
\hline $\mathrm{I} / \mathrm{II}$ & 81 & 32 & 49 & \\
\hline III/IV & 44 & 30 & 14 & \\
\hline Lymph node metastasis & & & & 0.916 \\
\hline YES & 45 & 26 & 19 & \\
\hline NO & 80 & 47 & 33 & \\
\hline
\end{tabular}

NOTE: $p$ values were derived by using Chi-square test. $(* p<0.05 . * * p<0.01)$.

died from CRC-related disorderswhile 8 patients died from other causes and were thus excluded. In addition, another 12 patients with data missing were also excluded during the follow-up time. The Kaplan-Meier analysis results for OS and DFS are displayed in Figure 2A and 2B respectively. As shown in Figure 2A and 2B, the log-rank test indicated that CRC patients with high CHRDL2 scores had a shorter overall or disease-free survival than CRC patients with low CHRDL2 scores (log-rank value 8.45 and 7.398; $P<0.01$ and $P<0.01$, respectively).

Next, we used univariate and multivariate Cox proportional hazards model analysis to analyze the effect of CHRDL2 on OS and DFS. Clinical and pathological characteristics including age, gender, tumor location, tumor diameter, TNM stage, depth of infiltration, histologic type and lymph node metastasis were considered to adjust the 
hazard ratio (HR). The univariate analysis revealed that tumor diameter, TNM stage, histologic type, and tumor CHRDL2 expression were prognostic indicators for OS, while multivariate analysis excluded depth of infiltration (Table 2). Regarding DFS, the univariate and multivariate analyses revealed that tumor diameter, TNM stage, histologic type, and tumor CHRDL2 expression were independent prognostic factors (Table 3 ).

\section{CHRDL2 expression in CRC cells}

We filtered colorectal cancer cell lines by examining CHRDL2 levels using QRT-PCR and western blotting. As shown in Figure $3 \mathrm{~A}$ and $3 \mathrm{~B}$, the ileocecal colorectal adenocarcinoma HCT8 and colon adenocarcinoma SW403 cell lines showed a relatively low expression of CHRDL2 while SW480 (colon adenocarcinoma), SW620 (colon adenocarcinoma) and HT29 (colon adenocarcinoma) had moderate CHRDL2 levels. On the other hand, HCT15 (colorectal cancer), HCT116 (colon adenocarcinoma), LoVo (colon adenocarcinoma) and $\mathrm{CaCo}-2$ (rectal adenosquamous) exhibited higher CHRDL2 levels. Finally, two CRC lines, CHRDL2 high-expressing HCT116 and CHRDL2 low-expressing HCT8 cells were selected from nine CRC cell lines for further studies.

\section{CHRDL2 promotes proliferation in CRC cells in vitro}

Our analyses of clinical samples suggested potential involvement of CHRDL2 in the development of CRC. However, the underlying mechanism remains unclear. Transfected by lentivirus vector, CHRDL2 gene over-expressing HCT8 cells and CHRDL2 gene knock-down HCT116 cells were established. We used western blotting to confirm the overexpression or silencing of CHRDL2 in stable cell lines (HCT8/ cont, HCT8/CHRDL2, HCT116/sh cont, HCT116/ shRNA\#1 and HCT116/shRNA\#3) (Figure 4A). We discarded the HCT116/shRNA\#2 clone due to its lower silencing efficiency. Given that CHRDL2 levels were positively correlated with tumor size, we examined the cell growth potential of the aforementioned clones. As shown in Figure 4B, cell growth was enhanced by the overexpression of CHRDL2 in HCT8 cells while attenuated by the silencing of CHRDL2 in HCT116 cells. EdU can be incorporated into DNA during active DNA synthesis, which can measure cell growth. EdU staining fluorescence images showed that the EdU positive cells (nuclei were stained red) ratio of HCT116/shRNA\#1(\#3) was lower than that of HCT116/sh cont, and the EdU positive cells ratio of HCT8/CHRDL2 was higher than that of HCT8/cont (Figure 4C). We next evaluated the effect of CHRDL2 on anchorage independent cancer cell growth (soft agar colony formation). As shown in Figure $4 \mathrm{D}$, the number of cancer cell colonies was significantly increased in CHRDL2 overexpressing HCT8/CHRDL2 cells compared with control HCT8/cont cells. On the other hand, the number of colonies decreased in CHRDL2-silenced HCT116/shRNA cells compared with control HCT116/cont cells.
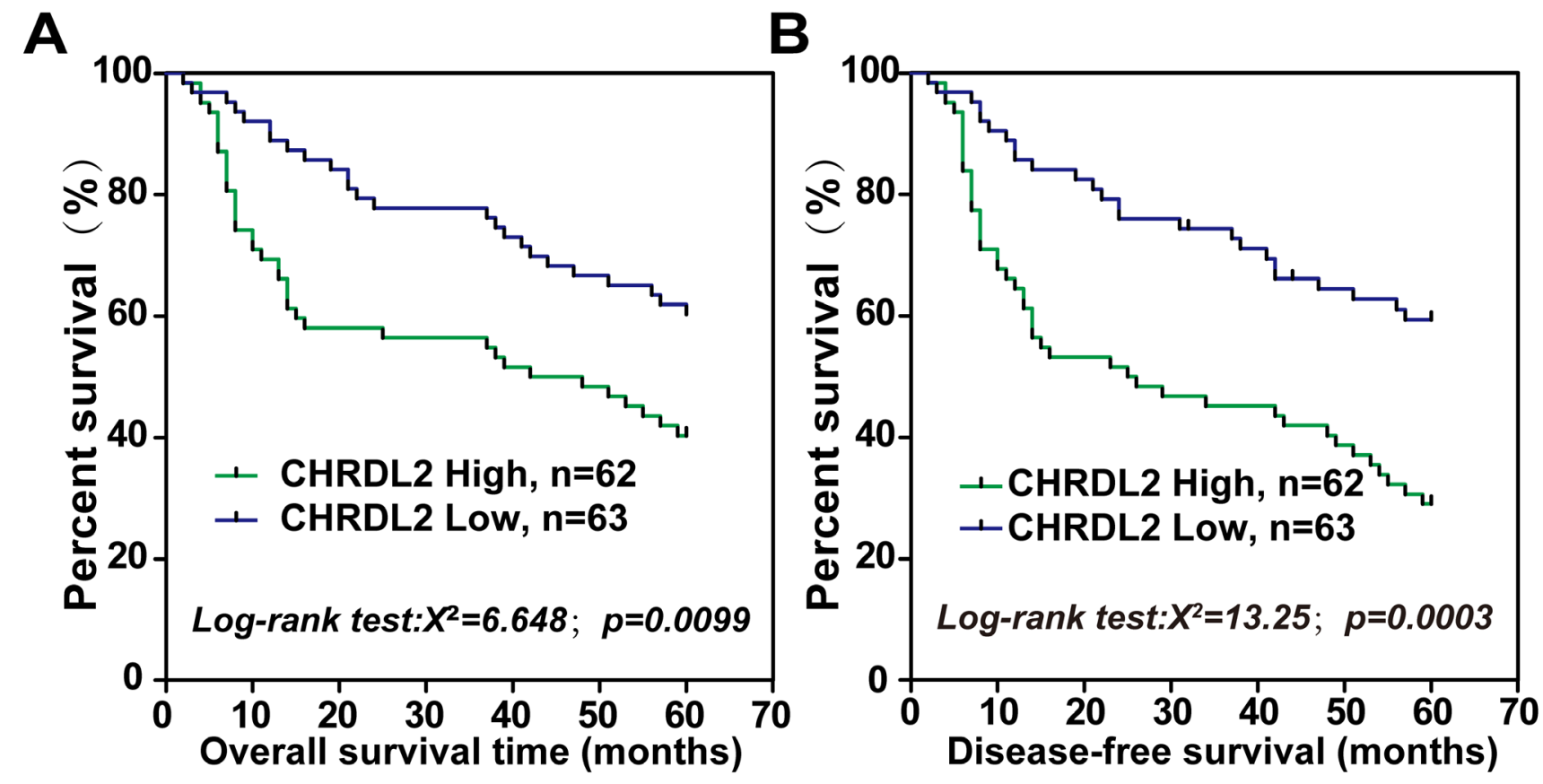

Figure 2: CHRDL2 is a potential predictor of poor prognosis in CRC patients. Kaplan-Meier curves displaying A. diseasefree survival and B. overall survival in patients with primary CRC. According to pathologic scores, CRC patients were divided into high CHRDL2 expression ( $>4)$ and low CHRDL2 expression $(\leq 4)$ groups. 
Table 2: Univariate and multivariate analysis of overall survival in CRC patients

\begin{tabular}{|c|c|c|c|c|c|c|c|}
\hline \multirow[b]{2}{*}{ Variables } & \multirow[b]{2}{*}{ No. of cases. } & \multicolumn{3}{|c|}{ Univariate analysis } & \multicolumn{3}{|c|}{ Multivariate analysis } \\
\hline & & HR ratio & $95 \% \mathrm{CI}$ & P-value & $\begin{array}{c}\mathrm{HR} \\
\text { ratio }\end{array}$ & $95 \% \mathrm{CI}$ & P-value \\
\hline Age(years) & & 1.004 & $0.985-1.204$ & 0.664 & & & \\
\hline$<60$ & 76 & & & & & & \\
\hline$\geq 60$ & 49 & & & & & & \\
\hline Gender & & 1.007 & $0.625-1.853$ & 0.79 & & & \\
\hline Female & 59 & & & & & & \\
\hline Male & 66 & & & & & & \\
\hline Tumor diameter(cm) & & 2.157 & $1.252-3.715$ & $0.006^{* *}$ & 2.158 & $1.245-3.741$ & $0.006 * *$ \\
\hline$\leq 5$ & 71 & & & & & & \\
\hline$>5$ & 54 & & & & & & \\
\hline Tumor location & & 0.664 & $0.377-1.169$ & 0.156 & & & \\
\hline Colon & 69 & & & & & & \\
\hline Rectum & 56 & & & & & & \\
\hline Depth of infiltration & & 1.185 & $0.815-1.723$ & 0.373 & & & \\
\hline $\begin{array}{l}\text { Submucosa,musculeris } \\
\text { propria }\end{array}$ & 28 & & & & & & \\
\hline Subserosa & 66 & & & & & & \\
\hline $\begin{array}{l}\text { To the surrounding } \\
\text { tissue }\end{array}$ & 31 & & & & & & \\
\hline Histologic type & & 1.518 & $1.053-2.189$ & $0.025^{*}$ & 1.696 & $1.147-2.506$ & $0.009 * *$ \\
\hline Well differentiated & 56 & & & & & & \\
\hline $\begin{array}{l}\text { Morderately } \\
\text { differentiated }\end{array}$ & 49 & & & & & & \\
\hline Poorly differentiated & 20 & & & & & & \\
\hline TNM staging & & 2.234 & $1.297-3.848$ & $0.004 * *$ & 2.489 & $1.481-4.399$ & $0.002 * *$ \\
\hline $\mathrm{I} / \mathrm{II}$ & 81 & & & & & & \\
\hline III/IV & 44 & & & & & & \\
\hline Lymph node metastasis & & 1.609 & $0.973-2.659$ & 0.064 & & & \\
\hline NO & 85 & & & & & & \\
\hline YES & 40 & & & & & & \\
\hline CHRDL2 expression & & 2.231 & $1.275-3.905$ & $0.005 * *$ & 2.139 & $1.207-3.791$ & $0.009 * *$ \\
\hline Low & 63 & & & & & & \\
\hline High & 62 & & & & & & \\
\hline
\end{tabular}

NOTE: $p$ values were derived by using Cox proportional hazards regression model. $\left({ }^{*} p<0.05 .{ }^{* *} p<0.01\right)$.

\section{CHRDL2 increased tumorigenicity of CRC cells in vivo}

Having demonstrated in vitro that CHRDL2 enhanced CRC cell growth, we next CHRDL2 affected in vivo xenograft tumor growth of CRC HCT116 and HCT8 cells. To this end, we flank-injected nude mice with the aforementioned CRC cells. Consistent with our in vitro proliferation results, the volume and weight of tumors from
HCT116/shRNA xenografts were lower compared with controls, while HCT8/CHRDL2 tumors had larger volume and weight than the controls (Figure 5A-5C). These data suggested that CHRDL2 promoted tumorigenicity of the CRC cells. We then embedded xenograft tumor tissues in paraffin for immunohistochemistry analyses. CHRDL2, ki67 and cyclin D1 antibodies were used for immunohistochemistry analyses. Ki67 staining was used as a cell proliferation marker, and cyclin D1 was used as a 
Table 3: Univariate and multivariate survival analysis of disease-free survival in CRC patients

\begin{tabular}{|c|c|c|c|c|c|c|c|}
\hline \multirow{2}{*}{ Variables } & \multirow{2}{*}{ No. of cases. } & \multicolumn{3}{|c|}{ Univariate analysis } & \multicolumn{3}{|c|}{ Multivariate analysis } \\
\hline & & HR ratio & $95 \% \mathrm{CI}$ & P-value & HR ratio & $95 \% \mathrm{CI}$ & P-value \\
\hline Age(years) & & 1.009 & $0.991-1.027$ & 0.349 & & & \\
\hline$<60$ & 76 & & & & & & \\
\hline$\geq 60$ & 49 & & & & & & \\
\hline Gender & & 0.911 & $0.554-1.498$ & 0.713 & & & \\
\hline Female & 59 & & & & & & \\
\hline Male & 66 & & & & & & \\
\hline Tumor diameter $(\mathrm{cm})$ & & 0.566 & $0.3629-0.8826$ & $0.012 *$ & 1.719 & $1.049-2.816$ & $0.019^{*}$ \\
\hline$\leq 5$ & 71 & & & & & & \\
\hline$>5$ & 54 & & & & & & \\
\hline Tumor location & & 0.996 & $0.609-1.628$ & 0.987 & & & \\
\hline Colon & 69 & & & & & & \\
\hline Rectum & 56 & & & & & & \\
\hline Depth of infiltration & & 1.055 & $0.749-1.485$ & 0.761 & & & \\
\hline $\begin{array}{l}\text { Submucosa, } \\
\text { musculeris propria }\end{array}$ & 28 & & & & & & \\
\hline Subserosa & 66 & & & & & & \\
\hline $\begin{array}{l}\text { To the surrounding } \\
\text { tissue }\end{array}$ & 31 & & & & & & \\
\hline Histologic type & & 1.61 & $1.155-2.245$ & $0.005^{* *}$ & 1.615 & $1.138-2.293$ & $0.007 * *$ \\
\hline Well differentiated & 56 & & & & & & \\
\hline $\begin{array}{l}\text { Morderately } \\
\text { differentiated }\end{array}$ & 49 & & & & & & \\
\hline Poorly differentiated & 20 & & & & & & \\
\hline TNM staging & & 1.716 & $1.055-2.791$ & $0.029 *$ & 1.849 & $1.119-3.057$ & $0.007 * *$ \\
\hline $\mathrm{I} / \mathrm{II}$ & 81 & & & & & & \\
\hline III/IV & 44 & & & & & & \\
\hline Lymph node metastasis & & 1.811 & $1.099-2.983$ & $0.02 *$ & & & \\
\hline NO & 85 & & & & & & \\
\hline YES & 40 & & & & & & \\
\hline CHRDL2 expression & & 1.956 & $1.188-3.221$ & $0.008^{* *}$ & 1.956 & $1.188-3.221$ & $0.008 *$ \\
\hline Low & 63 & & & & & & \\
\hline High & 62 & & & & & & \\
\hline
\end{tabular}

NOTE: $p$ values were derived by using Cox proportional hazards regression model. $(* p<0.05 . * * p<0.01)$.

cell cycle marker. As shown in Figure 5D, upregulation of CHRDL2 increased immunostaining of ki67 and cyclin D1 in grafted HCT8 cells while downregulation of CHRDL2 decreased immunostaining of ki67 and cyclin D1 in grafted HCT116 cells. Taken together, in agreement with our experiments in vitro, our data from in vivo experiments also indicated that CHRDL2 increased tumorigenicity of CRC cells.

\section{CHRDL2 blocked Smad1/5 signaling via binding to BMPs}

To identify cytokines that might interact with CHRDL2 in CRC cells, we performed co-IP assays to analyze the direct interactions between CHRDL2 and BMP2, BMP4, BMP6. As shown in Figure 6A and 6B, CHRDL2 could bind secreted mature forms of BMP2, 
BMP4, and BMP6 in cell culture media. To confirm this, we performed additional co-IP assays to determine whether recombinant CHRDL2 protein interacted with recombinant BMP2 protein. Our results revealed that CHRDL2 could bind the mature form of recombinant human BMP2 protein (Figure 6C).We then used western blotting to measure p-Smad1/5 levels, which are indicative of active BMP2 signaling. As shown in Figure 6D, adding100ng/ml BMP2 increased p-Smad1/5 levels in the cytosol and nucleus, and this effect was inhibited by CHRDL2 in a dose-dependent manner. We used immunofluorescence to determine the nuclear localization of $\mathrm{p}-\mathrm{Smad} 1 / 5$ and Smad4. When BMP2 was added, p-Smad1/5 in the cytosol of HCT116 cells increased, and p-Smad1/5 as well as Smad4 began to translocate from the cytosol to the nucleus (Figure 6E). Again, CHRDL2 inhibited these processes. Therefore, CHRDL2 suppressed Smad1/5 phosphorylation and nuclear translocation by blocking the upstream stimulator BMP2.

\section{CHRDL2 could bind to Activin A, but could not affect the Smad2/3 signal}

We performed co-IP assays to determine whether CHRDL2 binds to Activin A. In agreement with a previous study [22], we show in Supplementary Figure $2 \mathrm{~A}$ and $2 \mathrm{~B}$, that $\mathrm{CHRDL} 2$ could bind to secreted mature forms of Activin A in cell culture media. In addition, we found that CHRDL2 could bind to mature recombinant human Activin A (Supplementary Figure 2C). We also used western blotting to check the levels of p-Smad2 and p-Smad3, indicators of active Activin A signaling. As shown in Supplementary Figure 2D, when 100ng/ml of Activin A were added, we detected no change in $\mathrm{p}-\mathrm{Smad} 2$ and p-Smad3 levels in the cytosol or the nucleus. These data suggested that CHRDL2 could not affect p-Smad2 and p-Smad3 levels. We also used immunofluorescence to determine the localization of p-Smad2, p-Smad3 and Smad4. We found weak p-Smad2 expression and high p-Smad3 expression in HCT116 cells. Furthermore, Activin A and CHRDL2 did not affect the expression, the subcellular localizationor signaling of $\operatorname{Smad} 2 / 3$ (Supplementary Figure 2E).

\section{CHRDL2 blocked the effect of BMP2 on the proliferation inhibition and apoptosis inducing in CRC cells}

To further investigate the influence of CHRDL2 on BMP2 and cell growth, we examined the effect of CHRDL2 on cell-cycle progression. Our cell cycle analysis showed that BMP2 induced cell-cycle arrest in the $\mathrm{G} 0 / \mathrm{G} 1$ phase but the antagonist CHRDL2 promoted cell-cycle progression by increasing the number of cells in G2 phase (Figure 7A). Additionally, the cyclin-dependent
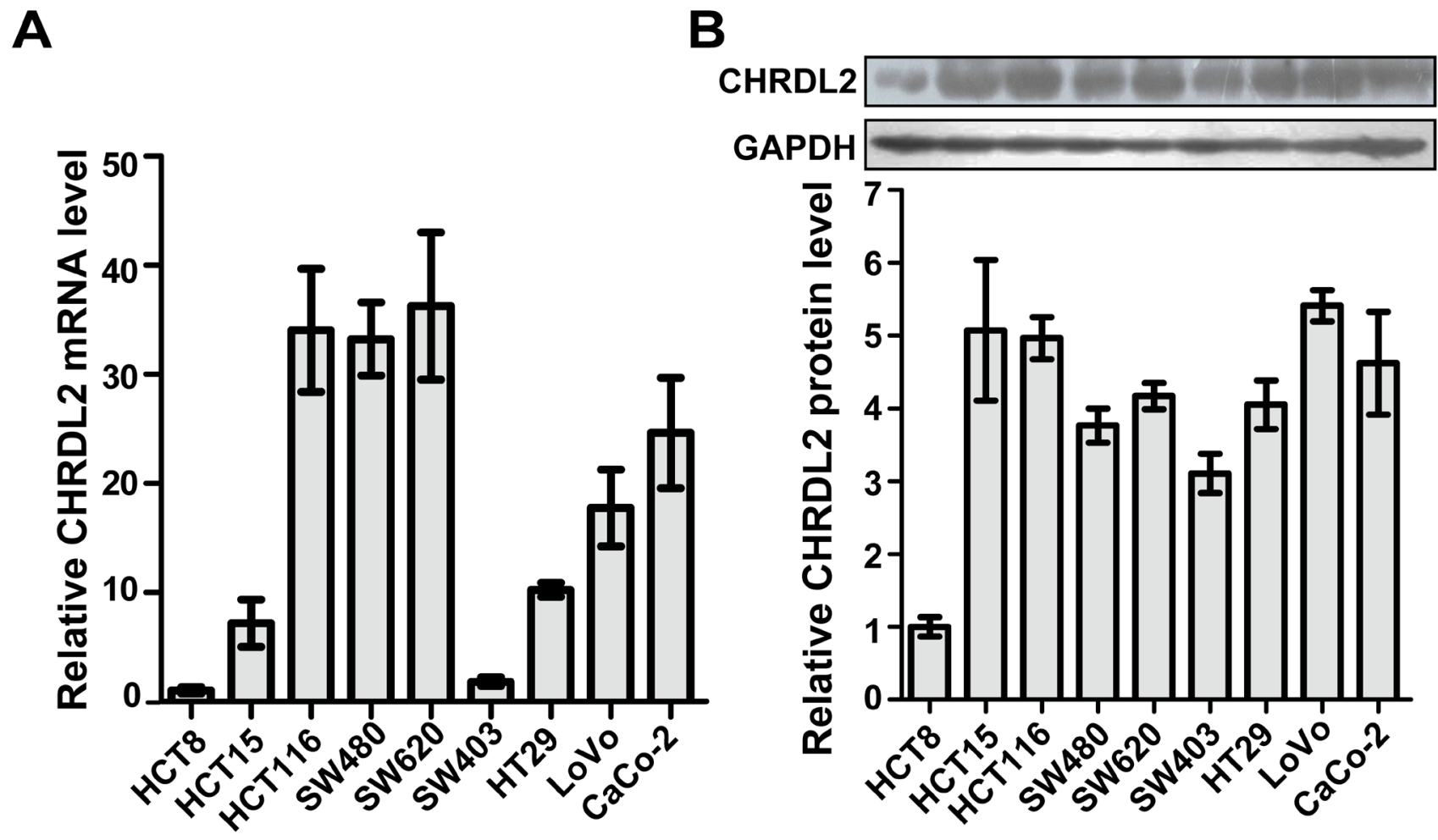

Figure 3: The mRNA and protein expression of CHRDL2 in nine CRC cell lines. A. CHRDL2 mRNA expression was measured by QRT-PCR in 9 human CRC cell lines (HCT8, HCT15, HCT116, SW480, SW620, SW403, HT29, LoVo, and CaCo-2). The mRNA level was normalized to 1 for HCT8. B. Protein levels of CHRDL2 in human CRC cell lines were measured by western blot. GAPDH was used as a loading control. The CHRDL2 protein level was normalized to 1 for HCT8. 
kinase inhibitor p21 was upregulated and the cell cycle progression related protein Cyclin D1 was downregulated in HCT116 cell treated with BMP2 while CHRDL2 blocked such effects (Figure 7C). These findings suggested that CHRDL2 promoted CRC cell growth.

Previous studies showed that BMPs induced apoptosis in many tumor cells [23-26]. Therefore, we tested whether the antagonist CHRDL2 inhibited the apoptotic effect of BMP2 in CRC cells. HCT116 cells were treated with BMP2 for $48 \mathrm{~h}$, with or without addition of CHRDL2. The cells were then harvested for apoptosis analysis by flow cytometry. Our results showed that BMP2 induced apoptosis, which was rescued by CHRDL2 (Figure 7B). In addition, we used western blotting to

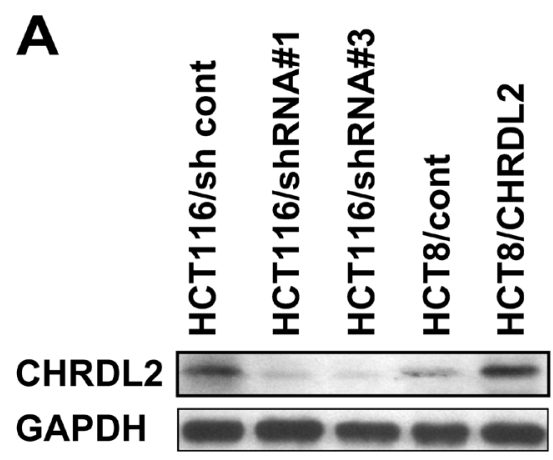

B

C

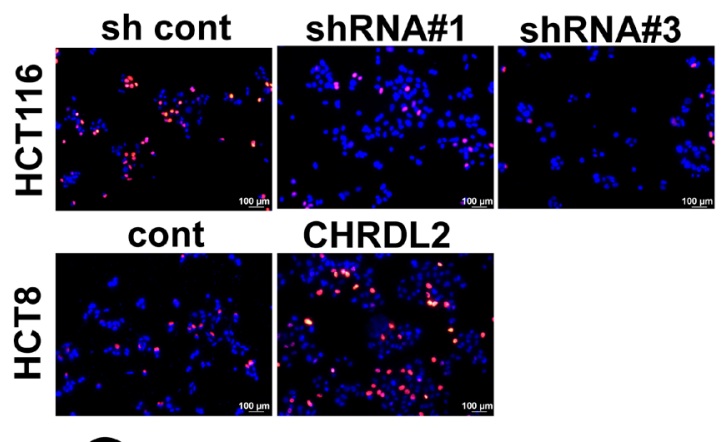

\section{HCT116}

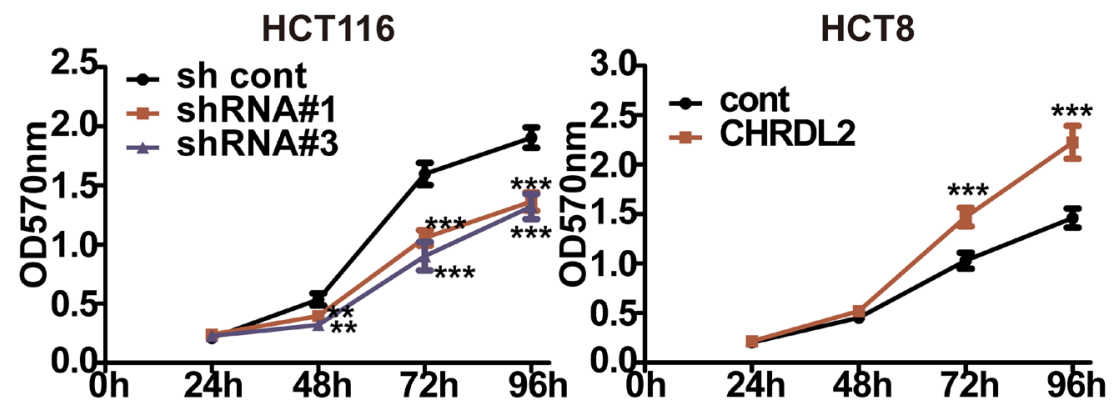

НСТ8

D


Figure 4: The effect of CHRDL2 on cell proliferation of CRC cells. A. Corresponding protein expression of CHRDL2 in lentivirus-transfected CRC cells were measured by western blot. HCT8 was stably transfected with either empty vector or CHRDL2 expression vector. HCT116 was stably transfected with either control vector or CHRDL2-shRNA vector. B. The MTT assay showed that the inhibition of CHRDL2 suppressed the proliferation of the HCT116 cell lines, while the overexpression of CHRDL2 increased the proliferation of the HCT8 cell lines in vitro. $(* * p<0.01$, ***p<0.001). C. EdU staining showingthat HCT116 cell proliferation decreases when CHRDL2 is silenced, while HCT8 cell proliferation increases when CHRDL2 is overexpressed. Six views were selected randomly in each slide, the percentage of EdU-positive cells in total cells of the field were quantified. D. The proliferation ability of the cells was observed by soft agar colony formation. Mean values from three independent experiments were taken as the results. $(* * p<0.01, * * * p<$ $0.001)$. The histograms show mean $\pm \mathrm{SE}$ of colony numbers. $(* * p<0.01, * * * p<0.001)$. 
measure the levels of two apoptosis related proteins, caspase 9 and caspase-3 (Figure 7C). We found that BMP2 significantly increased the rate of apoptosis (controls: 5.02 $\pm 0.66 \%$ versus BMP2: $17.27 \pm 0.65 \%, p<0.01)$ while CHRDL2 counteracted this effect (BMP2: $17.27 \pm 0.65 \%$ versus BMP2+ CHRDL2: 9.87 $\pm 0.34 \%, p<0.01)$. These observations indicated that CHRDL2 protected CRC cells from apoptosis.

\section{DISCUSSION}

BMP signaling has been shown to both suppress [26-31] and promote tumorigenesis [32-35]. TGF- $\beta$ and BMPs have also been proposed to exert opposing tumor suppressor and oncogenic roles in cancer [36], depending on cancer type and cell type [37]. BMP pathway mutations have been proposed as one of the causes such functional
A



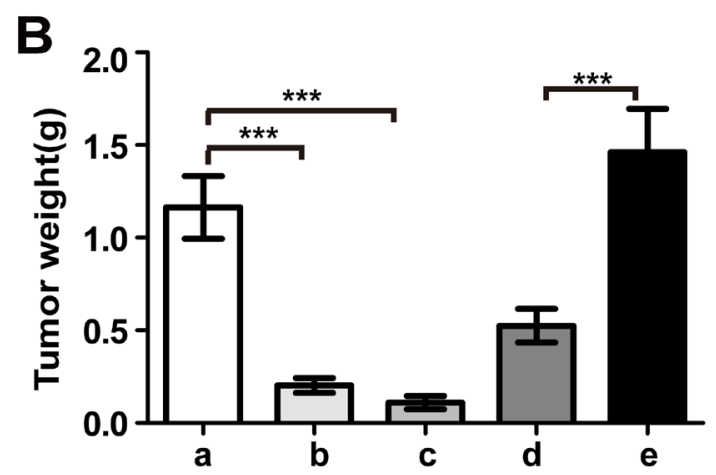

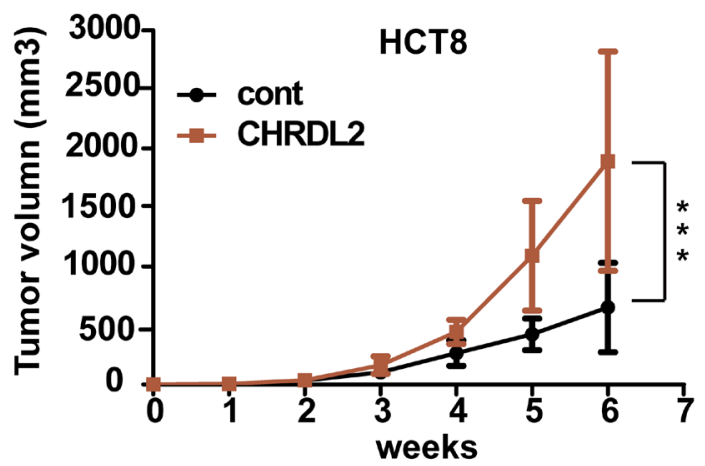

D

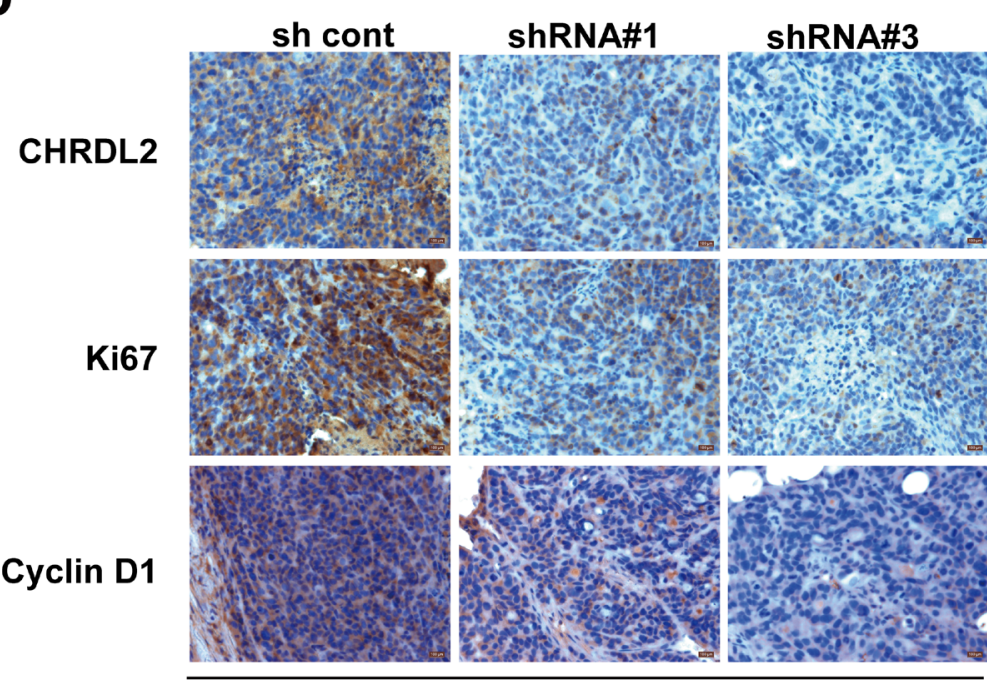

HCT116

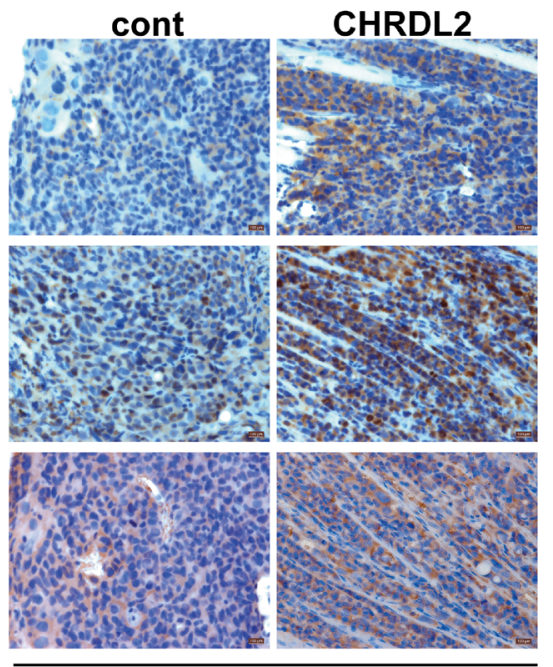

HCT8

Figure 5: The effect of CHRDL2 on tumor growth of subcutaneous xenograft of CRC cells in nude mice. A. Lentivirustransfected CRC cells (HCT116/sh control, HCT116/shRNA\#1, HCT116/shRNA\#3, HCT8/cont, HCT8/CHRDL2) were used for in vivo xenograft tumor growth assay, with $2 \times 10^{6}$ cells being subcutaneously injected into a flank of nude mice. B. The histograms show the weight of xenograft tumors $(* * P<0.01, * * * P<0.001)$. C. Cure graph showing the volume of xenograft tumors forevery week during6 weeks $(* * P<0.01, * * * P<0.001)$. D. IHC staining of CHRDL2, Ki67, and cyclin D1 expression in subcutaneous xenograft tumor. The scale bar represents $100 \mu \mathrm{m}$. 
A
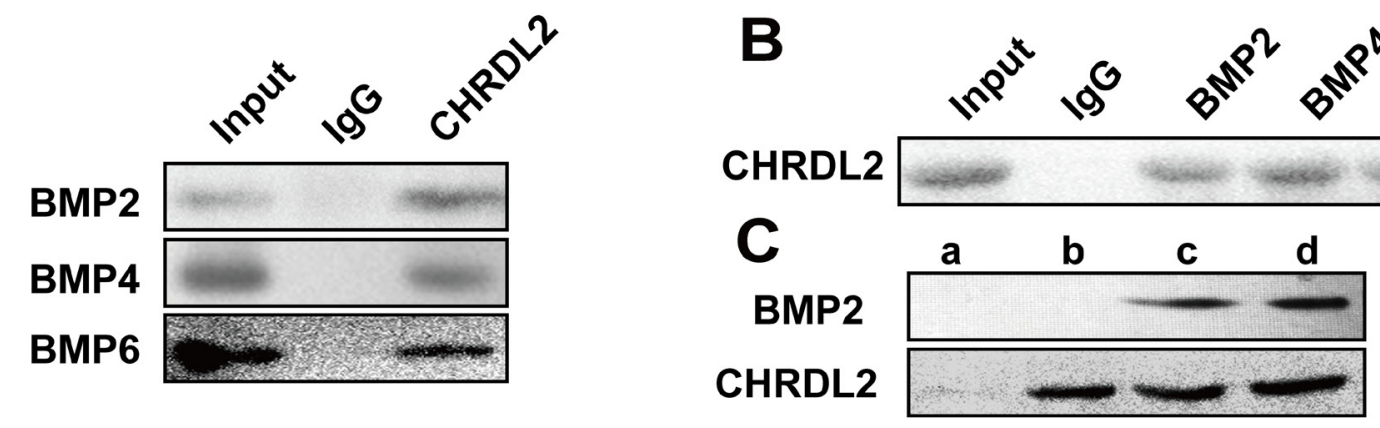

D

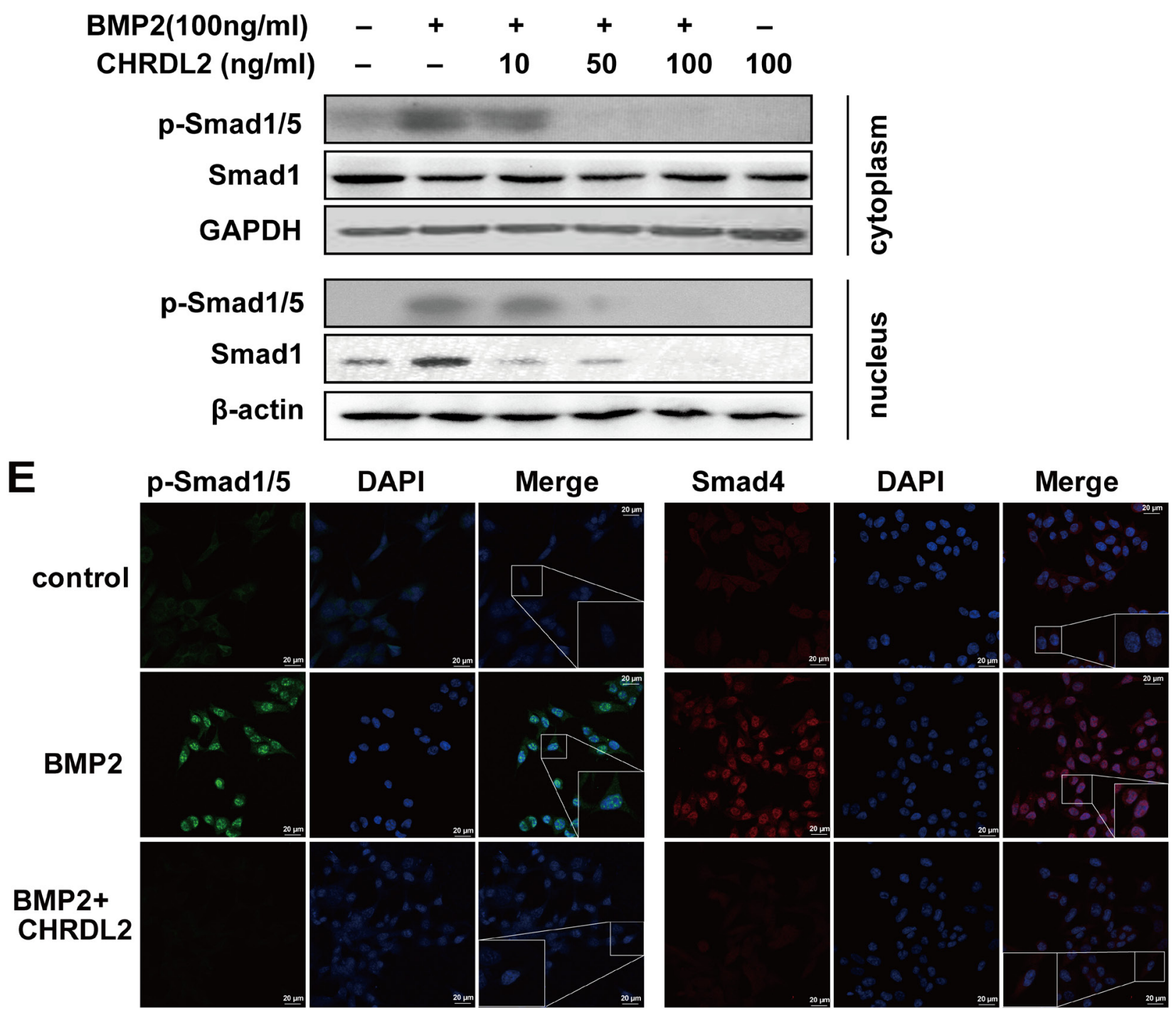

Figure 6: CHRDL2 binds to BMP2 and inhibits the phosphorylation of Smad1/5. A. Coimmunoprecipitation(co-IP) ofCHRDL2 and BMPs. HCT116 cell culture media were performed using anti-CHRDL2 and control (mouse IgG) antibodies. Immunoprecipitates and culture media were subjected to western blot analysis using anti-BMP2, anti-BMP4, and anti-BMP6 antibodies. B. Culture media were performed using anti-BMP2, anti-BMP4, anti-BMP6 and control (rabbit IgG) antibodies, and western blot analysis using anti-CHRDL2 antibody. C. Co-IP of recombinant CHRDL2 protein and the recombinant BMP2 protein. a: BMP-2 IP with anti-CHRDL2; b: CHRDL2 IP with anti-CHRDL2; c: mixture of BMP2 and CHRDL2; d: mixture of BMP2 and CHRDL2 IP with anti-CHRDL2. D. CHRDL2 inhibited the Smad1/5 phosphorylation of HCT116 cell induced by BMP2. The cytoplasm and nucleus protein extracts from HCT116 cells treated with BMP2, CHRDL2 or both for $1 \mathrm{~h}$ were probed for p-Smad1/5, Smad1. E. Immunofluorescence array for p-Smad1/5 and Smad4 in HCT116 cell. Merged images of HCT116 cells treated with different concentrations of BMP2, CHRDL2 or both for $1 \mathrm{~h}$, stained with DAPI and immunofluorescence stained with p-Smad1/5 and Smad4 respectively. Corresponding anti-rabbit secondary antibodies were conjugated with Alexa Fluor 488 and 555. 
A
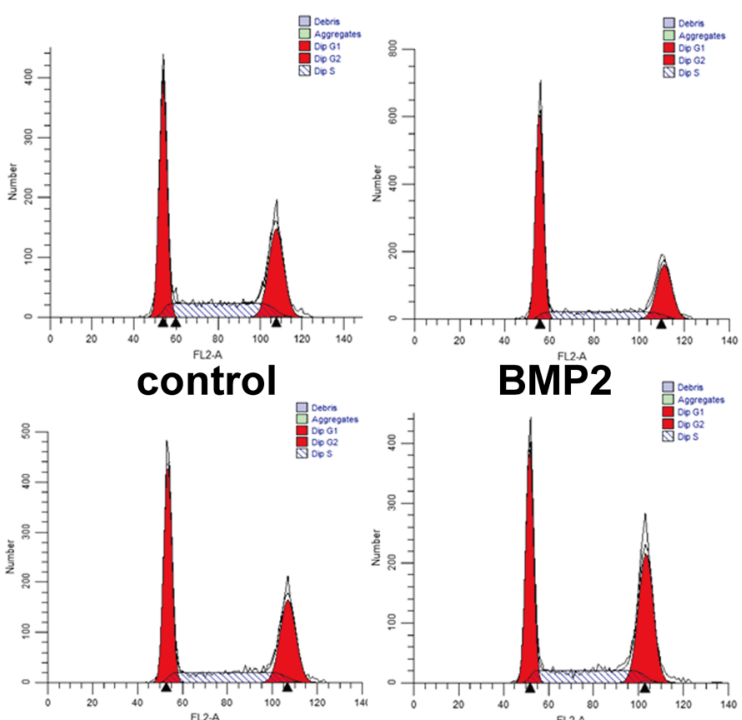

BMP2



BMP2+CHRDL2

CHRDL2

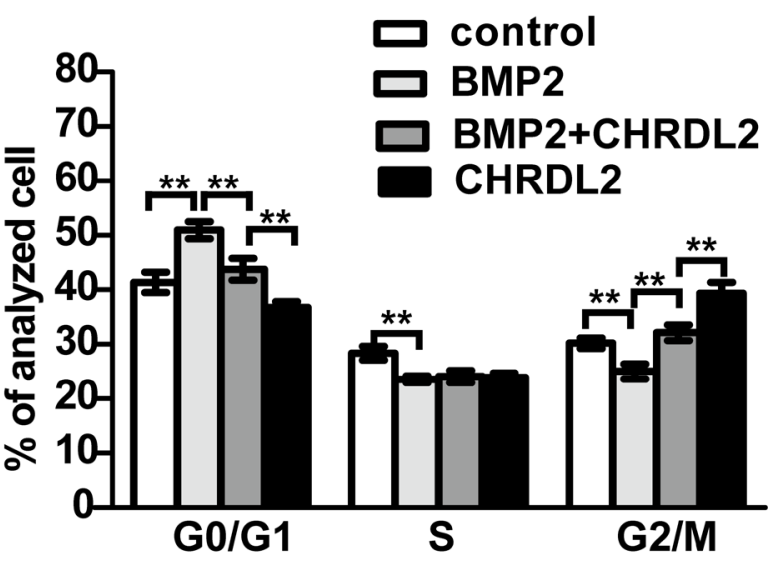

C

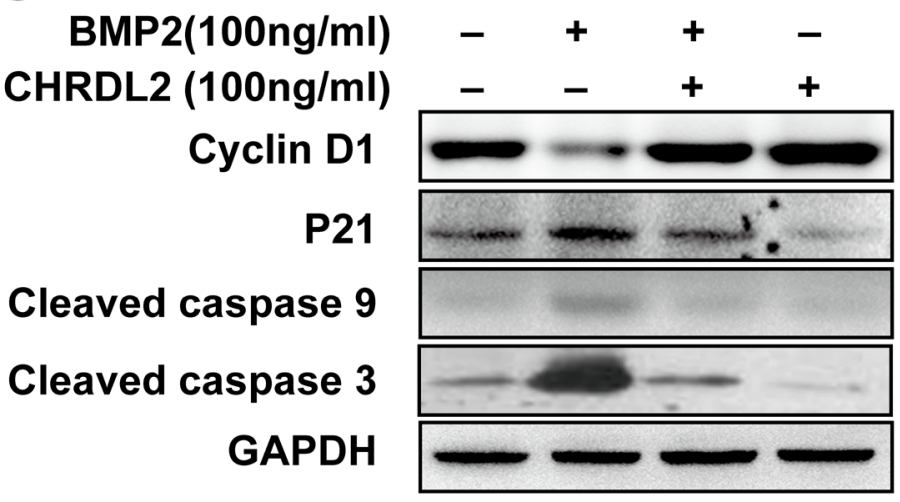

B
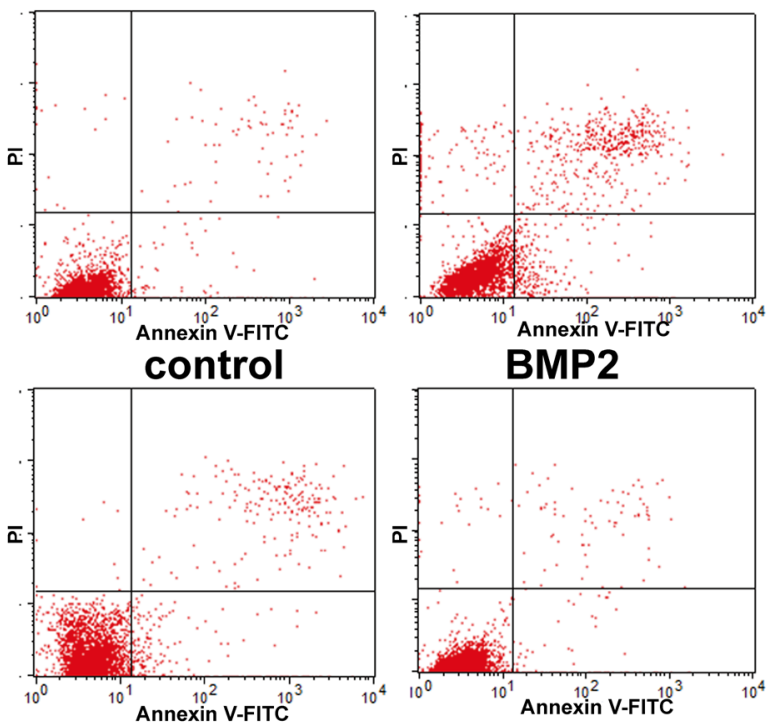

BMP2+CHRDL2 CHRDL2

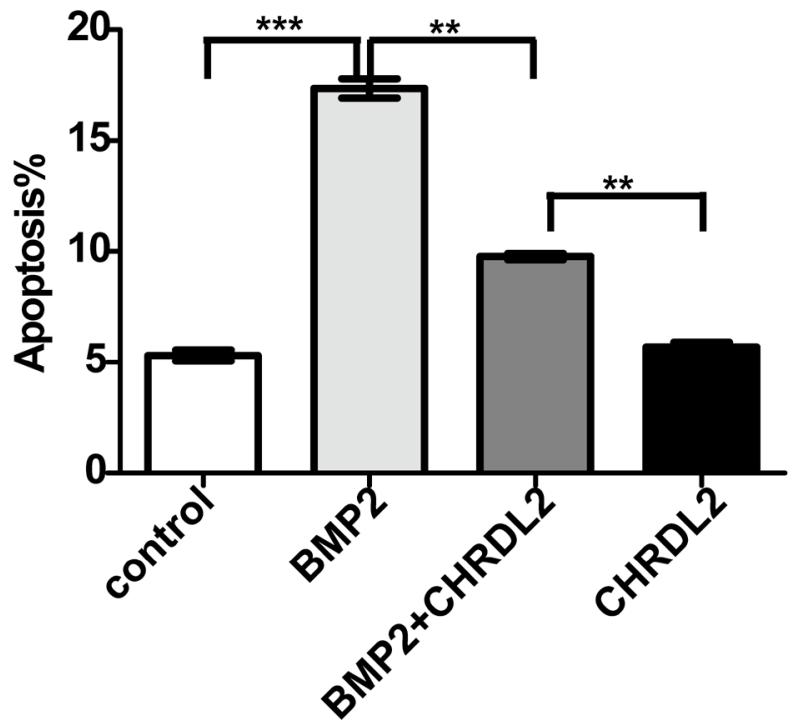

Figure 7: CHRDL2 blocks the BMP2 and attenuates the effect of promoting proliferation and inhibiting apoptosis induced by BMP2 in HCT116 cells. A. Cell-cycle analysis by flow cytometry in HCT116 cells treated with $100 \mathrm{ng} / \mathrm{ml}$ BMP2 or 100 $\mathrm{ng} / \mathrm{ml}$ CHRDL2. The histograms show the ratio of different cell phase populations (G0/G1, S and G2/M cells) in treated HCT116 cells. B. Apoptosis analysis by flow cytometry in HCT116 cells treated with $100 \mathrm{ng} / \mathrm{ml} \mathrm{BMP2}$ or $100 \mathrm{ng} / \mathrm{ml} \mathrm{CHRDL2.} \mathrm{The} \mathrm{histograms} \mathrm{show} \mathrm{the}$ apoptosis rate in treated HCT116 cells. C. Western blot analysis was used to measure the P21, Cyclin D1, Cleaved caspase 9 and Cleaved caspase 3 in the lysis of HCT116 cells treated with $100 \mathrm{ng} / \mathrm{ml} \mathrm{BMP2}$ or $100 \mathrm{ng} / \mathrm{ml} \mathrm{CHRDL2.}$ 
changes $[17,38]$. Previous studies have also demonstrated that BMPs could suppress $[16,17,39]$ or promote $[40$, 41] tumorigenesis specifically in CRC. Interestingly, the tumor-promoting effects shown for BMP4 stemmed from mutations in BMP4 or Smads [38, 42, 43] while the tumor-promoting effects of BMP7 did not depended on Smad4 [44].

The dynamic balance between proliferation and differentiation of intestinal crypt stem cells depends on the regulation of Wnt, Notch, and BMP signaling [13, 14]. Loss of BMP signaling resulting for overexpression of BMP antagonists can also contribute to recurrence and metastasis [38, 45]. Such antagonists include Noggin [46, 47], Gremlin [48, 49], and Follistatin [50]. In this study, we analyzed the expression levels of the BMP antagonist CHRDL2 to assess whether it can be used as a prognostic marker in CRC. Our results here demonstrated that CHRDL2 was upregulated in CRC samples. Moreover, CHRDL2 levels correlated with clinical features, such as tumor size, TNM staging, and tumor differentiation, and all of these parameters were independent factors for CRC survival. This is consistent with previous observations that CHRDL2 expression was increased in breast, lung and colon cancers, suggesting that CHRDL2 promotes tumorigenesis [21]. Our survival rate and Cox proportional hazards model analyses showed that high CHRDL2 expression levels correlate with poor prognosis in CRC.

Although previous research has suggested that CHRDL2 may function as an oncogene in breast, lung and colon cancers, it is not yet clear how CHRDL2 promotes cancer cell proliferation and tumorigenesis in CRC. In this study, we showed that CHRDL2 promoted CRC cell proliferation in vitro and $\mathrm{CRC}$ tumorigenesis in vivo. Our immunohistochemistry results showed that CHRDL2 increased the expression of ki67 and cyclin D1, which were tumor proliferation markers.

Since the binding specificity of CHRDL2 to BMPs or Activin A is still controversial, with contradicting results being reported [20, 22], we studied the effects of CHRDL2 on BMPs or Activin A. We tested whether CHRDL2 blocked BMP ligands by incubating antiCHRDL2 or BMP2, 4, 6 antibodies with HCT116 conditioned culture media followed by co-IP. Our results showed that CHRDL2 could bind BMP2, 4, 6. We further showed by co-IP that recombinant human CHRDL2 also interacted directly with recombinant human BMP2. These data suggested CHRDL2 can bind BMPs proteins. We then hypothesized that CHRDL2 might regulate the downstream Smad1/5 signaling pathways by binding and antagonizing BMPs. To test this hypothesis, we stimulated CRC HCT116 cell with BMP-2, with or without CHRDL2, and measured the phosphorylation levels of downstream signaling molecules smad $1 / 5$. Our results revealed that the effects of BMP 2 increasing p-Smad $1 / 5$ were inhibited by CHRDL2. In addition, we performed immunofluorescence experiments and showed that the nuclear translocation of p-Smad1/5 and Smad4 was inhibited by CHRDL2. Taken together, these data suggest that CHRDL2 inhibits BMPs and their downstream signaling.

Activin A ligands can bind their receptor (ACVR) and activate $\operatorname{Smad} 2 / 3$, which then translocate into the nucleus. Here, we found that although CHRDL2 could bind to Activin A, neither Activin A or CHRDL2 affected the activation of $\mathrm{Smad} 2 / 3$ and the nuclear translocation of Smad4 in HCT116 cells. Previous studies have reported that ACVR is lost or mutated in primary colon cancer, and that the Activin A-ACVR-Smad pathway is inactivated in CRC [51-53].

BMPs are multifunctional proteins that regulate proliferation, differentiation, and other biological functions in cells $[23,54-57]$. BMPs can also inhibit tumor proliferation and induce apoptosis $[15,16,24,26]$. As an antagonist of BMPs, we hypothesized that CHRDL2 might inhibit apoptosis in CRC cells and promote proliferation. Consistent with previous observations that antagonists of BMPs promote cancer cell proliferation and inhibit apoptosis [9, 23, 24, 26, 54, 55, 57-59], our data showed that CHRDL2 inhibited apoptosis induction by BMP2 in HCT116 cells, furthermore, our study revealed that CHRDL2 enhanced proliferation of CRC cell by upregulating Cyclin D1 and downregulating P21.

Our findings suggest that CHRDL2 could be used as a novel biomarker for CRC. We also provide evidence that CHRDL2 acts as an oncogene in human CRC, highlighting it as a potential novel therapeutic target.

\section{MATERIALS AND METHODS}

\section{Patients and samples}

Primary CRC tumor samples were obtained from 125 colorectal cancer patients treated at Putuo Hospital Affiliated to Shanghai University of Traditional Chinese Medicine (Shanghai, China) between 2005 and 2009. Sixty corresponding adjacent normal tissues were obtained at the same time. The study was approved by the ethics committee of Putuo Hospital. Written informed consent was obtained from all patients.

\section{Cell lines and cultures}

The HCT8, HCT15, HCT116, SW403, SW480, SW620, HT29, and LoVo cell lines were purchased from the Institute of Cell Biology (Shanghai, China).These cell lines were cultured in RPMI 1640 medium (Sigma). All media were supplemented with $10 \%$ fetal bovine serum (FBS, Gibco). All cell lines were maintained in a $5 \% \mathrm{CO} 2-$ humidified atmosphere at $37^{\circ} \mathrm{C}$.

\section{Antibodies and reagents}

Anti-CHRDL2 antibody (MAB2448) for western blot, anti-CHRDL2 antibody (AF2448) for immunohistochemistry, and HRP conjugate anti-mouse 
secondary antibodies (HAF007) were purchased from R\&D. Anti-BMP2 (18933-1-AP), anti-BMP4 (12492-1AP), anti-Activin A (60015-1-ig), and anti-BMP6 (60015$1-1 \mathrm{~g}$ ) antibodieswere obtained from Proteintech (China). Anti-Cyclin D1 (2978), anti-GAPDH (2118), anti- $\beta$-actin (12620), anti-Cleaved Caspase-9 (7237), anti-Cleaved Caspase-3 (9664), anti-Phospho-Smad1/5 (Ser463/465) (9516), anti-Smad1 (6944), anti-Smad4 (9515), anti-Smad2 (3122), anti-Phospho-Smad2 (Ser465/467) (11958), antiPhospho-Smad3 (Ser423/425) (8828), anti-Smad3 (9513), anti-P21 (2947) and HRP Conjugate anti-rabbit secondary antibodies (7075) were obtained from Cell Signaling Technology Inc. (USA). Alexa Fluor 488 conjugated antirabbit secondary antibodies (P0176) and Alexa Fluor 555 conjugated anti-rabbit secondary antibodies (P0179) were obtained from Beyotime (China). Purified recombinant protein of Homo sapiens CHRDL2 (TP320245) and BMP2 (TP750012) were purchased from ORIGENE (USA).

\section{Cloning of CHRDL2 gene open reading frame}

Five pairs of colorectal cancer tissues were used for CHRDL2 gene expression analysis. Total RNA was isolated from tissues using RNAiso Plus (Takara, Dalian, China), and First-strand cDNAs were prepared using the Primpscript RT reagent kit (Takara, Dalian, China). RT-PCR was performed using a Bio-Rad icycler and TaKaRa Taq HS Perfect Mix (Takara, Dalian, China). The CHRDL2 gene cDNA cloning primers used were: Forward, 5'-TCACCGAAGCTTATGGTTCCCGAGG TGAGG-3'; Reverse, 5'-TCACCGGGTACCGGTCTT TGTTATGTCTTGGTC-3'. PCR conditions were: $95^{\circ} \mathrm{C}$ for $5 \mathrm{~min}$, followed by 30 two-step cycles $\left(95^{\circ} \mathrm{C}\right.$ for 40 $\mathrm{s}, 60^{\circ} \mathrm{C}$ for $40 \mathrm{~s}$ and $72^{\circ} \mathrm{C}$ for $60 \mathrm{~s}$ ). RT-PCR products were analyzed on agarose gels and verified by DNA sequencing.

\section{Immunohistochemistry assay}

All tissue specimens were formalin-fixed, embedded in paraffin, sectioned serially to $5 \mu \mathrm{m}$ thickness slabs and mounted on glass slides. The reagents in subsequent process were purchased from Maixin Bio (FuZhou, China). Sections were incubated for $10 \mathrm{~min}$ in peroxidase blocking agent, washed for $3 \mathrm{~min}$ three times with phosphate-buffered saline (PBS), blocked with rabbit serum for $60 \mathrm{~min}$ at room temperature (RT), then incubated with antibody at $4^{\circ} \mathrm{C}$ overnight. The sections were washed three times with $\mathrm{PBS}$, incubated with biotin conjugate rabbit anti-goat secondary antibody for $10 \mathrm{~min}$ at RT, washed again with PBS, incubated with HRP conjugated second antibodies for $10 \mathrm{~min}$ at RT, then developed with diaminobenzidine solution (DAB) and counterstained with hematoxylin. Meanwhile, serial sections were HE stained. Each section was read independently by two pathologists. CHRDL2 expression was semi-quantitatively scored based on the intensity of staining: (0) negative; (1) weak (light yellow); (2) moderate (yellow) and (3) strong (brown), and on the percentage of positive cells: (0) unstained; (1) $\leq 25 \%$; (2) 26-50\%; (3) 51-75\%; and (4) $>75 \%$ positive cells.

\section{Flow cytometry}

HCT116 cells were plated in six-well plates at a density of $2 \times 10^{5}$ cells/well with cell culture medium and $10 \%$ fetal bovine serum (FBS). HCT116 cell were stimulated with BMP2 (100 ng/ml), CHRDL2 (100 ng/ $\mathrm{ml})$, BMP2 (100 ng/ml) + CHRDL2 (100 ng/ml) for $48 \mathrm{~h}$. Subsequently, the cells were harvested by trypsinization, washed once with cold PBS. To investigate cell-cycle progression, these cells were fixed in ice-cold $70 \%$ ethanol and stored at $4^{\circ} \mathrm{C}$ for $1 \mathrm{~h}$. After being washed once with cold PBS, the cells were subsequently stained for $30 \mathrm{~min}$ at RT in a solution containing $50 \mu \mathrm{g} / \mathrm{ml}$ PI (propidium iodide) and $10 \mu \mathrm{g} / \mathrm{ml}$ RNase A. Finally, flow cytometry analysis was performed using FACS Calibur system (Becton Dickinson, USA). PI was activated by a $488 \mathrm{~nm}$ laser, detected at $585 \mathrm{~nm}$, and the data were recorded by Cell Quest software. The percentages of cells in various phases of the cell cycle were analyzed using ModFit software. To investigate apoptosis, cells were stained with PI and anti-annexin-V antibody (Becton Dickinson, USA) at $4^{\circ} \mathrm{C}$ for $1 \mathrm{~h}$. Subsequently, cells were washed once with PBS and analyzed by FACS.

\section{Immunofluorescence array}

HCT116 cells were seeded on cover slips pre-coated with $0.01 \%$ poly-lysine at a density of 5000 cells per well in a 24-well chamber. The cells were treated with or without BMP2, CHRDL2, fixed in 4\% paraformaldehyde for $20 \mathrm{~min}$ at RT, permeabilized for $10 \mathrm{~min}$ in a $0.1 \%$ Triton X-100 followed by incubating in blocking buffer (Beyotime, China) (with 5\% BSA) for 60 min. Cells were subsequently washed three times with PBS, incubated with primary antibodies at $4^{\circ} \mathrm{C}$. Then the primary antibody was removed and the cells were washed five times with PBS. Alexa Fluor 488 and 555 conjugated anti-rabbit secondary antibodies were respectively added to the cells for $1 \mathrm{~h}$. The slides were finally washed three times to remove unbound secondary antibody. Cell nuclei were stained by DAPI prior to being observed using a Zeiss LSM 700 confocal microscope.

\section{Quantitative real-time PCR assay}

In all samples, sixty pairs of primary CRCs and their corresponding adjacent normal tissues were used for Quantitative real-time PCR (QRT-PCR) assay. Total RNA was isolated from tissues using RNAiso Plus, and the first-strand cDNAs was prepared using 
Primpscript RT reagent kit. QRT-PCR was performed using SYBR ${ }^{\circledR}$ Premix Ex Taq ${ }^{\mathrm{TM}}$ (Takara, Dalian, China) on CFX96 Real-time PCR System (Bio-Rad, USA). The following CHRDL2 gene primers were used: Forward, 5'-AAGATGAGGAAACTGAGGCT-3', Reverse, 5'-GGTCACTTTGTCTGGACTGGC-3'. GAPDH served as a control, F: 5'CATCCTGCTCCTCATCATCTTTC-3', R: 5'-TCCGTGTTCAGCTGCGGTA-3'. Each assay was performed in triplicate. PCR conditions were as follows: $95^{\circ} \mathrm{C}$ for $5 \mathrm{~min}$, followed by 40 two-step cycles $\left(95^{\circ} \mathrm{C}\right.$ for $20 \mathrm{~s}$ and $60^{\circ} \mathrm{C}$ for $30 \mathrm{~s}$ ). The fold change for CHRDL2 gene expression level was analyzed by the 2- $\Delta \Delta \mathrm{CT}$ method $\left[\Delta \Delta \mathrm{CT}=(\mathrm{CTCHRDL} 2-\mathrm{CTGAPDH})_{\text {tumor }}-\right.$ $\left.(\mathrm{CTCHRDL} 2-\mathrm{CTGAPDH})_{\text {normal }}\right]$. All experiments were performed in triplicate.

\section{Lentivirus and transduction}

The human CHRDL2 gene shRNA lentivirus was purchased from GENECHEM (Shanghai, China). The lentivirus vector system is composed of the vectors GV248-GFP/Puro, pHelper1.0 (gag/pol element) and Helper2.0 (VSVG element). Three targeting sequences of the shRNA were designed and inserted into GV248GFP/Puro vector. The CHRDL2 shRNA target sequences were shRNA\#1: AAGTCAGGAAGCAAGACTT; shRNA\#2: AACATAAGAAAGCCTGTGT; shRNA\#3: AAGTGAGCAATCGGATGAA. The human CHRDL2 gene overexpressing lentivirus was purchased from GenePharma (Shanghai, China). The lentivirus vector system is composed of the vectors pGLV4-EF1a-EGFP and three packaging plasmids (pGag/Pol, pVSV-G, $\mathrm{pRev}$ ). The cells were infected with lentivirus at an MOI of approximately 100 for $24 \mathrm{~h}$. Cells were then switched back into normal culture media.

\section{Cell proliferation assay}

The cultured cells were plated in a 96-well plate at a density of $3 \times 10^{3}$ cells/well with $10 \%$ FBS medium. MTT assay was performed for cell proliferation after 24 h, 48 h, 72 h, and 96 h. Cell culture medium solution containing $5 \mathrm{mg} / \mathrm{ml} \mathrm{MTT}$ was added to each well for $4 \mathrm{~h}$. The supernatant was removed from cultured cells and 150 $\mu 1$ DMSO were added to each well. Absorbance was read at $570 \mathrm{~nm}$ using a plate reader (Bio-Rad). Each sample was run in six wells and experiments were repeated three times. Soft agar colony formation was performed for cell proliferation assay in six-well plates. The low melt agar was purchased from Bio-Rad. The base layer was made up of $0.6 \%$ agar, $1 \times$ medium and $10 \%$ FBS. The upper layer contained 200 cells, $0.35 \%$ agar, $1 \times$ medium and $10 \%$ FBS. Cells were cultured at $37^{\circ} \mathrm{C}$ for two weeks. Colonies were visualized by microscopy. Soft agar colony formation assays were performed in triplicates for each cell line. EdU (5-Ethynyl-2-deoxyuridine) staining was performed for cell proliferation assay in a 24 -well chamber. The Cell-Light ${ }^{\mathrm{TM}}$ EdU DNA Cell Proliferation Kit (Ribobio, Guangzhou, China) was used to measure the proliferation rate of the cells according to the manufacturer's protocol. The percentage of EdU-positive cells represents the S-phase population and the cell's proliferation ability.

\section{Western blot and co-immunoprecipitation analysis}

The cells were lysed with M-PER Mammalian Protein Extraction Reagent with Protease inhibitor cocktail (100×) (Sangon biotech, china) and $1 \mathrm{mM}$ PMSF. The lysate were centrifuged at $4^{\circ} \mathrm{C}$ at $12000 \mathrm{~g}$ for $15 \mathrm{~min}$ and the supernatant was used for western blot. The protein concentration of measurement was done with the Bradford Coomassie Blue G-250 Method. Forty micrograms of protein were mixed with $5 \times$ SDS sample buffer and denatured by boiling for $10 \mathrm{~min}$. Denatured protein loaded onto $10 \%$ polyacrylamide SDS gels (PAGE-SDS) and transferred onto PVDF membranes (Millipore). Membranes were blocked in 5\% BSA for $2 \mathrm{~h}$ followed by incubation with primary antibodies overnight at $4^{\circ} \mathrm{C}$. After washing three times for $10 \mathrm{~min}$ in TBST, membranes were incubated with the HRP-conjugated secondary antibody for $2 \mathrm{~h}$ at RT. Subsequently, the membranes were washed again three times for $10 \mathrm{~min}$ in TBST and visualized using ECL Western Blotting Detection System (Millipore). The ratio of optical density of the bands was measured by a gel image analysis system (Bio-Rad) and normalized to $\beta$-actin. Co-immunoprecipitation (Co-IP) analysis was used to demonstrate direct interactions between CHRDL2 and BMP2, BMP4 and BMP6. The culture media for HCT116 cells was concentrated 10 -fold by ultrafiltration through an ultra filtration device (NMWL, 3kDa) (Millipore Amicon ${ }^{\circledR}$ Ultra, UFC900396). Before co-IP, concentrated culture media were pre-cleared by incubating with normal $\mathrm{IgG}$ for $3 \mathrm{~h}$ at $4^{\circ} \mathrm{C}$. These samples were incubated with anti-CHRDL2, anti-BMP2, anti-BMP4, anti-BMP6 and normal IgG antibodies overnight at $4{ }^{\circ} \mathrm{C}$, then incubated with protein $\mathrm{A}+\mathrm{G}$ agarose beads for $2 \mathrm{~h}$ at $4^{\circ} \mathrm{C}$. After being washed five times, protein $\mathrm{A}+\mathrm{G}$ agarose beads were mixed with SDS sample buffer, denatured by boiling for $10 \mathrm{~min}$ and loaded onto $10 \%$ PAGE-SDS for western blotting with corresponding antibodies. The coIP analyses of recombinant human CHRDL2 protein and recombinant human BMP2 proteins were done similarly.

\section{Xenograft tumor growth assay}

For the in vivo xenograft tumor growth assay, male nude mice [BALB/c nu/nu, 5-week-old, purchased from SLAC (Shanghai laboratory animal center, China)] were weighed and divided into five groups with ten animals/ group: (1) HCT116/sh control (cont); (2) HCT116/ shRNA\#1; (3) HCT116/shRNA\#3; (4) HCT8/cont; (5) 
HCT8/CHRDL2. Two million cells in $0.1 \mathrm{ml}$ of PBS were injected into subcutaneous tissues of each mouse. The volume of xenograft tumors was measured every week, and the tumor volume was calculated using the following equation: $\mathrm{V}=\mathrm{ab}^{2} / 2(\mathrm{~V}=$ volume; $\mathrm{a}=$ length; $\mathrm{b}=$ width $)$. Six weeks after injection, the tumor bearing mice were sacrificed and the tumors were excised and weighed.

\section{Statistical analysis}

Data were analyzed with single factor analysis of variance and a Student's t-test using SPSS 17.0 software. These data were represented as mean \pm SD. $P<0.05$ was considered statistically significant. Survival rate analysis was performed using the Kaplan-Meier method. The univariate and multivariate Cox proportional hazards model analysis were performed to identify factors associated with disease-free survival (DFS) and overall survival (OS). Multivariate analyses were performed to reduce the confounders' impact. These results were described by means of HR ratios (HRs) together with $95 \%$ confidence intervals (CIs), and $P$ values were based on the Wald test.

\section{ACKNOWLEDGMENTS}

This work was supported by the National Natural Science Foundation of China (grants no. 81473478 and no. 81303103), the Science Foundation for Shanghai Committee of Science Project (grant no. 13140902500), and the Science Foundation for Shanghai Municipal Health and Family Planning Commission (grant no. 20124065).

\section{CONFLICTS OF INTEREST}

No conflicts of interest to declare.

\section{REFERENCES}

1. Jemal A, Bray F, Center MM, Ferlay J, Ward E, Forman D. Global cancer statistics. CA Cancer J Clin. 2011; 61:69-90.

2. Kobayashi H, Mochizuki H, Sugihara K, Morita T, Kotake K, Teramoto T, Kameoka S, Saito Y, Takahashi K, Hase K, Oya M, Maeda K, Hirai T, Kameyama M, Shirouzu K, Muto T. Characteristics of recurrence and surveillance tools after curative resection for colorectal cancer: a multicenter study. Surgery. 2007; 141:67-75.

3. Onate-Ocana LF, Montesdeoca R, Lopez-Graniel CM, Aiello-Crocifoglio V, Mondragon-Sanchez R, CortinaBorja M, Herrera-Goepfert R, Oros-Ovalle C, GallardoRincon D. Identification of patients with high-risk lymph node-negative colorectal cancer and potential benefit from adjuvant chemotherapy. Japanese journal of clinical oncology. 2004; 34:323-328.
4. West NR, McCuaig S, Franchini F, Powrie F. Emerging cytokine networks in colorectal cancer. Nature reviews Immunology. 2015; 15:615-629.

5. Rooke HM, Crosier KE. The smad proteins and TGFbeta signalling: uncovering a pathway critical in cancer. Pathology. 2001; 33:73-84.

6. Bello-DeOcampo D, Tindall DJ. TGF-betal/Smad signaling in prostate cancer. Curr Drug Targets. 2003; 4:197-207.

7. Lu J, Wu Y, Sousa N, Almeida OF. SMAD pathway mediation of BDNF and TGF beta 2 regulation of proliferation and differentiation of hippocampal granule neurons. Development. 2005; 132:3231-3242.

8. Goumans MJ, Lebrin F, Valdimarsdottir G. Controlling the angiogenic switch: a balance between two distinct TGF-b receptor signaling pathways. Trends in cardiovascular medicine. 2003; 13:301-307.

9. Zhang J, Ge Y, Sun L, Cao J, Wu Q, Guo L, Wang Z. Effect of bone morphogenetic protein-2 on proliferation and apoptosis of gastric cancer cells. Int J Med Sci. 2012; 9:184-192.

10. Gao X, Wei S, Lai K, Sheng J, Su J, Zhu J, Dong H, $\mathrm{Hu} \mathrm{H}, \mathrm{Xu} \mathrm{Z}$. Nucleolar follistatin promotes cancer cell survival under glucose-deprived conditions through inhibiting cellular rRNA synthesis. J Biol Chem. 2010; 285:36857-36864.

11. Kim M, Yoon S, Lee S, Ha SA, Kim HK, Kim JW, Chung J. Gremlin-1 induces BMP-independent tumor cell proliferation, migration, and invasion. PLoS One. 2012; 7:e35100.

12. Thawani JP, Wang AC, Than KD, Lin CY, La Marca F, Park P. Bone morphogenetic proteins and cancer: review of the literature. Neurosurgery. 2010; 66:233-246; discussion 246.

13. Kosinski C, Li VS, Chan AS, Zhang J, Ho C, Tsui WY, Chan TL, Mifflin RC, Powell DW, Yuen ST, Leung SY, Chen X. Gene expression patterns of human colon tops and basal crypts and BMP antagonists as intestinal stem cell niche factors. Proc Natl Acad Sci U S A. 2007; 104:15418-15423.

14. Simons BD, Clevers H. Stem cell self-renewal in intestinal crypt. Exp Cell Res. 2011; 317:2719-2724.

15. Hardwick JC, Kodach LL, Offerhaus GJ, van den Brink GR. Bone morphogenetic protein signalling in colorectal cancer. Nat Rev Cancer. 2008; 8:806-812.

16. Beck SE, Jung BH, Fiorino A, Gomez J, Rosario ED, Cabrera BL, Huang SC, Chow JY, Carethers JM. Bone morphogenetic protein signaling and growth suppression in colon cancer. Am J Physiol Gastrointest Liver Physiol. 2006; 291:G135-145.

17. Loh K, Chia JA, Greco S, Cozzi SJ, Buttenshaw RL, Bond CE, Simms LA, Pike T, Young JP, Jass JR, Spring KJ, Leggett BA, Whitehall VL. Bone morphogenic protein 3 inactivation is an early and frequent event in colorectal cancer development. Genes Chromosomes Cancer. 2008; 47:449-460. 
18. Kodach LL, Wiercinska E, de Miranda NF, Bleuming SA, Musler AR, Peppelenbosch MP, Dekker E, van den Brink GR, van Noesel CJ, Morreau H, Hommes DW, Ten Dijke P, Offerhaus GJ, Hardwick JC. The bone morphogenetic protein pathway is inactivated in the majority of sporadic colorectal cancers. Gastroenterology. 2008; 134:1332-1341.

19. Kodach LL, Bleuming SA, Musler AR, Peppelenbosch MP, Hommes DW, van den Brink GR, van Noesel CJ, Offerhaus GJ, Hardwick JC. The bone morphogenetic protein pathway is active in human colon adenomas and inactivated in colorectal cancer. Cancer. 2008; 112:300-306.

20. Nakayama N, Han CY, Cam L, Lee JI, Pretorius J, Fisher S, Rosenfeld R, Scully S, Nishinakamura R, Duryea D, Van G, Bolon B, Yokota T, Zhang K. A novel chordin-like BMP inhibitor, CHL2, expressed preferentially in chondrocytes of developing cartilage and osteoarthritic joint cartilage. Development. 2004; 131:229-240.

21. Wu I, Moses MA. BNF-1, a novel gene encoding a putative extracellular matrix protein, is overexpressed in tumor tissues. Gene. 2003; 311:105-110.

22. Oren A, Toporik A, Biton S, Almogy N, Eshel D, Bernstein J, Savitsky K, Rotman G. hCHL2, a novel chordinrelated gene, displays differential expression and complex alternative splicing in human tissues and during myoblast and osteoblast maturation. Gene. 2004; 331:17-31.

23. Zhang Z, Zheng J, Zhao Y, Li G, Batres Y, Luo M, Wan M, Ying S. Overexpression of activin A inhibits growth, induces apoptosis, and suppresses tumorigenicity in an androgen-sensitive human prostate cancer cell line LNCaP. Int J Oncol. 1997; 11:727-736.

24. Kawamura C, Kizaki M, Yamato K, Uchida H, Fukuchi Y, Hattori Y, Koseki T, Nishihara T, Ikeda Y. Bone morphogenetic protein-2 induces apoptosis in human myeloma cells with modulation of STAT3. Blood. 2000; 96:2005-2011.

25. Lagna G, Nguyen PH, Ni W, Hata A. BMP-dependent activation of caspase- 9 and caspase- 8 mediates apoptosis in pulmonary artery smooth muscle cells. Am J Physiol Lung Cell Mol Physiol. 2006; 291:L1059-1067.

26. Ye L, Kynaston H, Jiang WG. Bone morphogenetic protein-9 induces apoptosis in prostate cancer cells, the role of prostate apoptosis response-4. Mol Cancer Res. 2008; 6:1594-1606.

27. Ye L, Kynaston H, Jiang WG. Bone morphogenetic protein-10 suppresses the growth and aggressiveness of prostate cancer cells through a Smad independent pathway. J Urol. 2009; 181:2749-2759.

28. Yan H, Zhu S, Song C, Liu N, Kang J. Bone morphogenetic protein (BMP) signaling regulates mitotic checkpoint protein levels in human breast cancer cells. Cell Signal. 2012; 24:961-968.

29. Wang L, Park P, Zhang H, La Marca F, Claeson A, Valdivia J, Lin CY. BMP-2 inhibits the tumorigenicity of cancer stem cells in human osteosarcoma OS99-1 cell line. Cancer Biol Ther. 2011; 11:457-463.
30. Wang C, Hu F, Guo S, Mi D, Shen W, Zhang J, Qiao Y, Zhu T, Yang S. BMP-6 inhibits MMP-9 expression by regulating heme oxygenase-1 in MCF-7 breast cancer cells. J Cancer Res Clin Oncol. 2011; 137:985-995.

31. Ying X, Sun Y, He P. Bone Morphogenetic Protein-7 Inhibits EMT-Associated Genes in Breast Cancer. Cell Physiol Biochem. 2015; 37:1271-1278.

32. Theriault BL, Shepherd TG, Mujoomdar ML, Nachtigal MW. BMP4 induces EMT and Rho GTPase activation in human ovarian cancer cells. Carcinogenesis. 2007; 28:1153-1162.

33. Peng J, Yoshioka Y, Mandai M, Matsumura N, Baba T, Yamaguchi K, Hamanishi J, Kharma B, Murakami R, Abiko K, Murphy SK, Konishi I. The BMP signaling pathway leads to enhanced proliferation in serous ovarian cancer-a potential therapeutic target. Molecular carcinogenesis. 2015.

34. Park Y, Kim JW, Kim DS, Kim EB, Park SJ, Park JY, Choi WS, Song JG, Seo HY, Oh SC, Kim BS, Park JJ, Kim YH, Kim JS. The Bone Morphogenesis Protein-2 (BMP-2) is associated with progression to metastatic disease in gastric cancer. Cancer Res Treat. 2008; 40:127-132.

35. Park Y, Kang MH, Seo HY, Park JM, Choi CW, Kim YH, Kim IS, Kim JS, Oh SC. Bone morphogenetic protein-2 levels are elevated in the patients with gastric cancer and correlate with disease progression. Med Oncol. 2010; 27:1192-1199.

36. Alarmo EL, Kallioniemi A. Bone morphogenetic proteins in breast cancer: dual role in tumourigenesis? Endocr Relat Cancer. 2010; 17:R123-139.

37. Ikushima H, Miyazono K. TGFbeta signalling: a complex web in cancer progression. Nat Rev Cancer. 2010; 10:415-424.

38. Voorneveld PW, Kodach LL, Jacobs RJ, Liv N, Zonnevylle AC, Hoogenboom JP, Biemond I, Verspaget HW, Hommes DW, de Rooij K, van Noesel CJ, Morreau $H$, van Wezel T, Offerhaus GJ, van den Brink GR, Peppelenbosch MP, et al. Loss of SMAD4 alters BMP signaling to promote colorectal cancer cell metastasis via activation of Rho and ROCK. Gastroenterology. 2014; 147:196-208 e113.

39. Hardwick JC, Van Den Brink GR, Bleuming SA, Ballester I, Van Den Brande JM, Keller JJ, Offerhaus GJ, Van Deventer SJ, Peppelenbosch MP. Bone morphogenetic protein 2 is expressed by, and acts upon, mature epithelial cells in the colon. Gastroenterology. 2004; 126:111-121.

40. Deng H, Makizumi R, Ravikumar TS, Dong H, Yang W, Yang WL. Bone morphogenetic protein-4 is overexpressed in colonic adenocarcinomas and promotes migration and invasion of HCT116 cells. Exp Cell Res. 2007; 313:1033-1044.

41. Motoyama K, Tanaka F, Kosaka Y, Mimori K, Uetake H, Inoue $\mathrm{H}$, Sugihara K, Mori M. Clinical significance of BMP7 in human colorectal cancer. Ann Surg Oncol. 2008; 15:1530-1537. 
42. Deng H, Ravikumar TS, Yang WL. Overexpression of bone morphogenetic protein 4 enhances the invasiveness of Smad4-deficient human colorectal cancer cells. Cancer Lett. 2009; 281:220-231.

43. Lubbe SJ, Pittman AM, Matijssen C, Twiss P, Olver B, Lloyd A, Qureshi M, Brown N, Nye E, Stamp G, Blagg J, Houlston RS. Evaluation of germline BMP4 mutation as a cause of colorectal cancer. Hum Mutat. 2011; 32:E1928-1938.

44. Grijelmo C, Rodrigue C, Svrcek M, Bruyneel E, Hendrix A, de Wever O, Gespach C. Proinvasive activity of BMP-7 through SMAD4/src-independent and ERK/Rac/JNKdependent signaling pathways in colon cancer cells. Cell Signal. 2007; 19:1722-1732.

45. Xie W, Rimm DL, Lin Y, Shih WJ, Reiss M. Loss of Smad signaling in human colorectal cancer is associated with advanced disease and poor prognosis. Cancer J. 2003; 9:302-312.

46. Brabletz S, Schmalhofer O, Brabletz T. Gastrointestinal stem cells in development and cancer. J Pathol. 2009; 217:307-317.

47. Sharov AA, Mardaryev AN, Sharova TY, Grachtchouk M, Atoyan R, Byers HR, Seykora JT, Overbeek P, Dlugosz A, Botchkarev VA. Bone morphogenetic protein antagonist noggin promotes skin tumorigenesis via stimulation of the Wnt and Shh signaling pathways. Am J Pathol. 2009; 175:1303-1314.

48. Karagiannis GS, Berk A, Dimitromanolakis A, Diamandis EP. Enrichment map profiling of the cancer invasion front suggests regulation of colorectal cancer progression by the bone morphogenetic protein antagonist, gremlin-1. Molecular oncology. 2013; 7:826-839.

49. Sneddon JB, Zhen HH, Montgomery K, van de Rijn M, Tward AD, West R, Gladstone H, Chang HY, Morganroth GS, Oro AE, Brown PO. Bone morphogenetic protein antagonist gremlin 1 is widely expressed by cancerassociated stromal cells and can promote tumor cell proliferation. Proc Natl Acad Sci U S A. 2006; 103:14842-14847.

50. Karagiannis GS, Treacy A, Messenger D, Grin A, Kirsch R, Riddell RH, Diamandis EP. Expression patterns of bone morphogenetic protein antagonists in colorectal cancer desmoplastic invasion fronts. Molecular oncology. 2014; 8:1240-1252.
51. Deacu E, Mori Y, Sato F, Yin J, Olaru A, Sterian A, Xu Y, Wang S, Schulmann K, Berki A, Kan T, Abraham JM, Meltzer SJ. Activin type II receptor restoration in ACVR2deficient colon cancer cells induces transforming growth factor-beta response pathway genes. Cancer Res. 2004; 64:7690-7696.

52. Jung BH, Beck SE, Cabral J, Chau E, Cabrera BL, Fiorino A, Smith EJ, Bocanegra M, Carethers JM. Activin type 2 receptor restoration in MSI-H colon cancer suppresses growth and enhances migration with activin. Gastroenterology. 2007; 132:633-644.

53. Jung B, Doctolero RT, Tajima A, Nguyen AK, Keku T, Sandler RS, Carethers JM. Loss of activin receptor type 2 protein expression in microsatellite unstable colon cancers. Gastroenterology. 2004; 126:654-659.

54. Ramachandran A, Marshall ES, Love DR, Baguley BC, Shelling AN. Activin is a potent growth suppressor of epithelial ovarian cancer cells. Cancer Lett. 2009; 285:157-165.

55. Burdette JE, Jeruss JS, Kurley SJ, Lee EJ, Woodruff TK. Activin A mediates growth inhibition and cell cycle arrest through Smads in human breast cancer cells. Cancer Res. 2005; 65:7968-7975.

56. Kaneda H, Arao T, Matsumoto K, De Velasco MA, Tamura D, Aomatsu K, Kudo K, Sakai K, Nagai T, Fujita Y, Tanaka K, Yanagihara K, Yamada Y, Okamoto I, Nakagawa K, Nishio K. Activin A inhibits vascular endothelial cell growth and suppresses tumour angiogenesis in gastric cancer. Br J Cancer. 2011; 105:1210-1217.

57. Dalkin AC, Gilrain JT, Bradshaw D, Myers CE. Activin inhibition of prostate cancer cell growth: selective actions on androgen-responsive LNCaP cells. Endocrinology. 1996; 137:5230-5235.

58. Kim YI, Kim BH, Khang I, Cho BN, Lee HK. Cell growth regulation through apoptosis by activin in human gastric cancer SNU-16 cell lines. Oncol Rep. 2009; 21:491-497.

59. Zheng Y, Wang X, Wang H, Yan W, Zhang Q, Chang X. Bone morphogenetic protein 2 inhibits hepatocellular carcinoma growth and migration through downregulation of the PI3K/AKT pathway. Tumour biology. 2014; 35:5189-5198. 